\title{
Research on Innovation and Entrepreneurship Education Reform in Jilin Province Colleges and Universities in Transition
}

\author{
Shao Chen \\ Baicheng Normal University, Baicheng, China \\ 99455399@qq.com
}

Keywords: Colleges and Universities in Transition, Innovation and Entrepreneurship, Education Reform

\begin{abstract}
In accordance with the requirements of relevant national policies, some colleges and universities in China will be transformed into technological-oriented colleges and universities in the future, but before that, most of the universities in our country were biased towards academic research. There are great differences between the operation mode of colleges and universities before and after transformation. Under this background, the reform of innovation and entrepreneurship education in colleges and universities in our country is also facing a great challenge. How to carry out the reform of innovation and entrepreneurship education in colleges and universities at this stage needs to be analyzed from many levels and angles.
\end{abstract}

\section{Introduction}

According to the actual situation of colleges and universities in transition in China, in the near future, Chinese colleges and universities should be divided into academic research universities and technology-applied colleges according to theory and practice. According to the current policy requirements of our country, some colleges and universities need to be transformed into technology-applied colleges from the original academic research universities. The transformation of colleges and universities and the reform of innovative entrepreneurship education are two different educational reforms, but in fact, the transformation of colleges and universities means that the structure of colleges and universities themselves will undergo great changes. The innovation and entrepreneurship education in colleges and universities is based on the actual situation of colleges and universities. The structure of colleges and universities has changed, and there have been many changes in Entrepreneurship Education attached to them. Therefore, the reform of innovation and entrepreneurship education in transforming colleges and universities must follow up the process of university transformation in real time, update the information of university transformation in time, and do a good job in evaluating the transformation plan of colleges and universities, and carry out innovation and entrepreneurship reform of colleges and universities in transition in an appropriate way.

\section{An Outline of the Connotation of Innovation and Entrepreneurship Education in Colleges and Universities}

\subsection{The Historical Change of the Concept of Innovation and Entrepreneurship Education.}

Innovation and entrepreneurship education is the guidance work of innovative entrepreneurship education aimed at college students and combining with the actual situation of universities and students. Innovation and entrepreneurship education was originally the only idea of entrepreneurship education, which originated in the United States. After it was introduced into China, our country combined with the characteristics of the new era and the national conditions of our country, developed it into innovative entrepreneurship education, which is regarded as an important basic work in various colleges and universities. Entrepreneurship education was put forward in 1989, and UNESCO put forward the new educational concept of entrepreneurship 
education for the first time, and raised its international status to the same level as academic and vocational education. The first practice of entrepreneurship education was in the United States, and in 1947, Harvard Business School offered its first entrepreneurship course worldwide. With the deepening of international research on entrepreneurship education, at the Tokyo Conference in 1991, scholars from all over the world distinguished entrepreneurship education from narrow sense and broad sense. The narrow sense of entrepreneurship education refers to the entry of entrepreneurial education as an undertaking training course into the daily work of higher education, while the broad sense of entrepreneurship education means that higher education will upgrade the original goal of cultivating high-quality talents into the training of creative high-quality talents. However, both the narrow sense and the broad sense of entrepreneurship education, its purpose is to increase the survival ability of college graduates in the economic society and enhance the possibility of their important contribution to the society [1]. Then, in 1998, the international higher education circle put forward the new concept of "the melting pot of entrepreneur", which is to let the university become a huge melting pot, and to train the college students to become the new generation of entrepreneurs. At the same time, this concept also requires that colleges and universities should pay attention to cultivate students innovative spirit and strengthen students entrepreneurship education, so as to enhance their pioneering ability in economic society.

Then, the entrepreneurship education enters into China, and the higher education circle of our country injects the new concept, that is, the innovation concept, and develops the entrepreneurship education into the innovation and entrepreneurship education. At the same time, it is pointed out that we should pay attention to the cultivation of students innovative spirit and ability while undertaking entrepreneurship education, and on the basis of this, we emphasize the cultivation of practical ability, which combines the theory of innovative entrepreneurship with practical action. Entrepreneurship education has also been rapidly developed and improved because of Chinese innovation. The innovation and entrepreneurship education reform in our country is different from the independent initiation of foreign universities and colleges. The innovation and entrepreneurship education reform in our country is led by the government and is more systematic and comprehensive. In 2002, the Ministry of Education first identified the pilot unit of innovation and entrepreneurship education, that is, Fudan University, a total of nine universities to carry out innovative entrepreneurship education for the pilot. Then, in 2010, the Ministry of Education issued a directive to launch innovation and entrepreneurship education on a large scale, requiring colleges and universities to actively carry out innovation and entrepreneurship education. It is also the symbol of the further development of innovation education in our country that the survival and innovation ability of the high quality talents trained in various colleges and universities should be raised to a new level in the economy and society.

\subsection{The Importance of Carrying out Innovation and Entrepreneurship Education on a Big Scale.}

Strengthening innovation and entrepreneurship education is the inevitable choice of Chinese economic development in the new era. At present, from the actual situation of economic development in the context of the new era in our country, strengthening innovation and entrepreneurship education is an important support for strengthening the ability of economic and social innovation in our country. If the innovation and entrepreneurship education of higher education in our country can be concretely carried out to all colleges and departments, there will be a large number of innovative and entrepreneurial talents with strong universal ability flowing into the economic society on a large scale, which can greatly promote the current economic development of our country. At present, the population of our country is still increasing, higher education is popularizing, and the number of college graduates is increasing rapidly. However, the resources are shrinking, especially with the development of high technology driven by the productivity. The pressure of employment is increasing at a very obvious rate, and with the deepening of environmental damage, environmental restrictions on people are also increasing, and the cost of various production activities is also increasing. In order to achieve stable economic 
development, a lasting balance between man and development and nature and to prevail in the competition of the world economy, we can only rely on innovation to inject vitality into economic development. At the same time, it also depends on the innovation of science and technology to further balance the sharp contradiction between economic development and natural environment. Both the innovation of science and technology and the innovation of structure and system management need a lot of researchers, managers and laborers to be full of innovative spirit and innovative entrepreneurial ability. Therefore, innovation and entrepreneurship have been raised to the height of national strategy and become a very important driving force in the economic development of our country. Generally speaking, the economic development of our country is mainly promoted by the progress of production technology, the innovation of marketing means and the reform of management system. The progress of production technology needs a scientific innovation to realize. The innovation of marketing means needs to be accomplished by the creativity of the managers, and the reform of the management system also needs the managers to innovate and practice continuously. In general, the key to economic development lies in the spirit of innovation and the ability of innovation and entrepreneurship. These people are generally derived from various colleges and universities, which are based on the innovation and entrepreneurship education in various colleges and universities. If we can carry out the work of innovation and entrepreneurship education in higher education, we will be able to cultivate creative and high quality talents and provide high quality energy power for the development of society and economy [2].

Strengthening innovation and entrepreneurship education is the inevitable trend of the development of education in the new era. As far as the concrete form of education of our country is concerned, most of our higher education lacks professional quality and vocational skill education, most of them are only vocational theory education, and vocational quality and vocational skill education need to study in special vocational education schools. However, as far as the reality of our country is concerned, the social status of colleges and universities is much higher than that of ordinary vocational schools. Therefore, the graduates of colleges and universities in our country often need to go through certain social practice in order to transform the theoretical knowledge of higher education into practical abilities, which is very detrimental to the social, economic and personal development of students. Therefore, the combination of higher education and vocational education will be the inevitable trend of education development in China. In recent years, colleges and universities in our country have been expanding their enrollment again and again. Colleges and universities have gradually changed from the original training of top management to the training of technical personnel at the grass-roots level. The popularization of higher education means that the inheritors of higher education will become the most basic unit of the economy and society, that is, as colleges and universities have moved from excellence to popularity this year, they must also consider the basic professional abilities of their students so that they will have excellent working abilities after graduation, which can make graduates have a certain degree of competitiveness in the current super-high employment pressure. Therefore, with the continuous development of education in China, the integration of higher education and vocational education is an inevitable trend. The connection point between the two is innovation and entrepreneurship education, so that higher education in colleges and universities will not stick to theoretical education, nor will they completely indulge in vocational education, that is the best combination of higher education and vocational education.

Strengthening innovation and entrepreneurship education is the best way to realize the transformation of colleges and universities. The transformation of colleges and universities has become the focus of education reform in China, and it has become one of the important tasks of education in China in recent years to realize the transformation of some colleges and universities. Among the existing colleges and universities in our country, the most easy to realize the transformation is the newly built local ordinary undergraduate colleges and universities, because of the new construction, all aspects of construction are not mature, and the resistance to promote reform is relatively small. The focal point of university transformation task of our country is this 
kind of newly-built local ordinary undergraduate colleges and universities. The form or concept of the technical applied college is similar to the existing vocational school, but the social status of the vocational school is generally lower than that of the undergraduate or above. Therefore, many colleges and universities are very repellent to the transformation into technical applied universities, especially some universities with great fame and long time of establishment, they do not approve of the transformation of colleges and universities, and the direct transformation will have very great resistance. Innovation and entrepreneurship education can sow the seeds of transformation in colleges and universities without any exclusion, and lay the foundation for the future transformation work. Innovation and entrepreneurship education does not occupy too much time in colleges and universities, does not affect the normal teaching work, but can enhance innovation and entrepreneurship ability of students, enhance their competitiveness in employment, at the same time, it can also preliminarily realize the application of technology in colleges and universities, that is the best way for the transformation of colleges and universities [3].

\section{The Ways to Realize the Innovation and Entrepreneurship Education under the Transformation Environment of Colleges and Universities}

At present, there are three main modes of innovation and entrepreneurship education in Colleges and universities in China: the one is the main operation type, the second is the skill training type, and the three is the actual combat training mode. The purpose of innovation and entrepreneurship education is to improve students ability of innovation and to cultivate students spirit of innovation. And the technology applied university after the transformation can achieve this goal very well. Therefore, colleges and universities in our country should take advantage of the good atmosphere of the transformation of colleges and universities, absorb and learn from other regions and other successful examples of innovative entrepreneurship education in other countries to develop their own innovative entrepreneurship education cause, and perfect the theory of innovation and entrepreneurship in our country, enrich the connotation of innovative entrepreneurship theory and enhance the feasibility of innovative entrepreneurship education in China.

\subsection{Creating a Cultural Atmosphere of Innovation and Entrepreneurship.}

Education is a very long-term work and career, as long as the existence of human beings, education will also exist. For education, the success of any individual, the performance of the individual has a time to spend, only the "atmosphere" can last. Therefore, in terms of innovation and entrepreneurship education, the most important task is to create a cultural atmosphere of innovation and entrepreneurship, encourage students to actively participate in innovative entrepreneurship education, learn innovative entrepreneurial knowledge and enhance innovative entrepreneurial ability. At present, it is only a preliminary innovation and entrepreneurship education in colleges and universities [4]. The most important thing is not to carry out innovative entrepreneurship education. For the human being as a whole, the temporary gains and losses are too small. The most important thing is to create a cultural atmosphere of innovation and entrepreneurship and to raise the students enthusiasm for learning. Only in this way can the work of innovation and entrepreneurship education be carried out well.

\subsection{Optimizing the Curriculum System of Innovation and Entrepreneurial Education.}

Curriculum system refers to the learning order of different courses in a professional teaching, that is, the scientific ranking of what students firstly learn, what they then learn, and what they learn at last from admission to graduation. Excellent curriculum system can help students learn yielding twice the result with half the effort, reduce the study pressure of students and teachers burden, help students to construct the knowledge system of scientific system, and strengthen the students professional ability and the ability of applying theory. At present, the curriculum system of innovative entrepreneurship education in colleges and universities is unreasonable or even imperfect. The current education of innovation and entrepreneurship is not the mainstream in the education of colleges and universities, but helps students to enhance their personal ability in 
addition to learning professional knowledge. Therefore, the current curriculum system should be based on the premise of adapting to the students, combined with the characteristics and shortcomings of each college students to carry out innovative entrepreneurship training, enhance their innovative entrepreneurial ability.

\subsection{Establishing a Perfect Evaluation System of Innovation and Entrepreneurship Education.}

The establishment of any new thing must go through constant practice and improvement. The same is true of the innovation and entrepreneurship education in our country. While all colleges and universities have carried out the work of innovation and entrepreneurship education successively, we should also construct a perfect evaluation system of innovation and entrepreneurship education, find problems in practice and give feedback in time to enable colleges and universities to timely find their own work problems and timely correction. A perfect evaluation system can timely feedback work results, so that the exploration of innovation and entrepreneurship educators see the door to success to improve their work enthusiasm. At the same time, it also can make students see their own strengths and weaknesses in innovative entrepreneurship education, facilitate students to play their own strengths and gaps, improve the social evaluation and satisfaction of innovation and entrepreneurship education [5].

\subsection{Establishing and Perfecting the Guarantee System of Innovation and Entrepreneurship Education.}

The purpose of innovation and entrepreneurship is to improve the practical ability and practical innovation ability of students. There is success and failure in practice, and there are gains in success and losses in failure. At the same time, practice also needs a certain platform for students to play their own space. Therefore, innovation and entrepreneurship education also needs to establish a sound security system, from the government to colleges and universities to enterprises, protecting innovative entrepreneurial practice of students, but also in practice to give timely guidance to students to help students to sublimate themselves and improve their professional ability in practice.

\section{Conclusion}

With the development of educational undertakings in China and the increasing enrollment of colleges and universities, the number of people with higher education has continuously increased, and the higher education in our country has realized the progress from the elitism to the base of grass - roots, and so, colleges and universities in our country must also begin to bring vocational education into teaching. Under the circumstances that some colleges and universities are transformed into technologically applied colleges and universities, they should actively carry out innovation and entrepreneurship education, and ensure the smooth development of innovation and entrepreneurship education in all aspects in order to cultivate innovative spirit of students, enhancing their ability of innovation and entrepreneurship and employment competitiveness.

\section{References}

[1] Multi-point breakthrough and further promotion of innovation and entrepreneurship education reform [J]. China Higher Education, 2016(21):4.

[2] Mao Jie. An analysis of the path of strengthening innovation and entrepreneurship education under the background of university transformation and development [J]. Henan Social Sciences, 2016, 24(09):104-108.

[3] Zhang Guoliang. Exploration on the path of innovation and entrepreneurial education for college students in local universities from the perspective of transformation and development [J]. Journal of Xi'an University (Social Sciences Edition), 2017, 20(01):103-106.

[4] Lang Hua. Exploration of innovation and pioneering education in colleges and universities [J]. Continue Education Research, 2017(06):28-30.

[5] Guo Mingshun. Innovation and entrepreneurship education in colleges and universities based on economic transformation and upgrading [J]. Modern Education Management, 2014(12):56-59. 